\title{
IMPLEMENTASI PENDIDIKAN KARAKTER SEMANGAT KEBANGSAAN DAN CINTA TANAH AIR PADA SEKOLAH BERLATAR BELAKANG ISLAM DI KOTA PASURUAN
}

\author{
Aji Bagus Priyambodo \\ Program Studi Psikologi, Fakultas Pendidikan Psikologi, Universitas Negeri Malang \\ ajibagus88@gmail.com
}

\begin{abstract}
Abstrak
Semakin berkembangnya radikalisme beragama di tengah masyarakat menjadi ancaman bagi kesatuan bangsa Indonesia. Salah satu upaya strategis menangkal radikalisme beragama di Indonesia adalah melalui program pendidikan karakter di sekolah. Tujuan penelitian ini adalah untuk mengetahui bagaimana implementasi pendidikan karakter semangat kebangsaan dan cinta tanah air di sekolah berlatar belakang islam di Kota Pasuruan. Pendekatan penelitian yang digunakan adalah pendekatan kualitatif termasuk dalam jenis penelitian studi kasus. Subyek penelitian ini adalah kepala sekolah, para guru dan para siswa di beberapa sekolah berlatar belakang islam di Kota Pasuruan. Hasil penelitian menunjukkan bahwa telah terdapat komitmen pada ketiga pimpinan sekolah yang berlatar belakang Islam di Kota Pasuruan untuk melaksanakan pendidikan karakter semangat kebangsaan dan cinta tanah air namun penyediaan sarana prasarana yang menunjang masih minim, evaluasi dan tindak lanjut keberhasilan pendidikan karakter juga masih belum dilaksanakan.
\end{abstract}

Kata Kunci: pendidikan karakter, semangat kebangsaan, cinta tanah air

Pendidikan pada dasarnya adalah usaha sadar dan terencana untuk mewujudkan suasana belajar dan proses pembelajaran agar peserta didik secara aktif mengembangkan potensi dirinya untuk memiliki kekuatan spiritual keagamaan, pengendalian diri, kepribadian, kecerdasan, akhlak mulia serta keterampilan yang diperlukan dirinya, masyarakat, bangsa dan Negara (Ormrod, 2008). Menurut Ki Hajar Dewantoro (dalam Indrakusuma, 1973) pendidikan adalah daya upaya untuk memajukan bertumbuhnya budi pekerti (kekuatan batin dan karakter), pikiran (intellect) dan tubuh anak. Bagian-bagian itu tidak boleh dipisahkan agar kita dapat memajukan kesempurnaan hidup anak.

Menurut Tim Dosen KTP FIP IKIP Malang (1996), pendidikan nasional adalah pendidikan yang berdasarkan Pancasila dan Undang-Undang Dasar Negara Republik Indonesia Tahun 1945, yang berakar pada nilainilai agama, kebudayaan nasional Indonesia dan tanggap terhadap tuntutan perubahan zaman. Pendidikan nasional berfungsi mengembangkan kemampuan dan membentuk watak serta peradaban bangsa yang bermartabat dalam rangka mencerdaskan kehidupan bangsa.
Pendidikan nasional bertujuan untuk berkembangnya potensi peserta didik agar menjadi manusia yang beriman dan bertakwa kepada Tuhan Yang Maha Esa, berakhlak mulia, sehat, berilmu, cakap, kreatif, mandiri dan menjadi warga negara yang demokratis serta bertanggung jawab (Danim, 2006).

Menurut Pedoman Pelaksanaan Pendidikan Karakter (Kemdikbud, 2011) pendidikan karakter merupakan pendidikan nilai, pendidikan budi pekerti, pendidikan moral, pendidikan watak yang bertujuan mengembangkan kemampuan peserta didik untuk memberi keputusan baik buruk, memelihara apa yang baik dan mewujudkan kebaikan itu dalam kehidupan sehari-hari dengan sepenuh hati. Pada intinya pendidikan karakter bertujuan membentuk bangsa yang tangguh, kompetitif, berakhlak mulia, bermoral, bertoleran, bergotong royong, berjiwa patriotik, berkembang dinamis, berorientasi ilmu pengetahuan dan teknologi yang semuanya dijiwai oleh iman dan takwa kepada Tuhan Yang Maha Esa berdasarkan Pancasila.

Pendidikan karakter berfungsi: 1. Mengembangkan potensi dasar agar berhati baik, berpikiran baik dan berprilaku baik. 
2.Memperkuat dan membangun prilaku bangsa yang multikultur (memperkuat perilaku yang sudah baik). 3.Meningkatkan peradaban bangsa yang kompetitif dalam pergaulan dunia.(penyaring budaya yang kurang sesuai dg nilai - nilai luhur Pancasila). Pembangunan karakter dilakukan dengan pendekatan sistematik dan integratif dengan melibatkan keluarga, satuan pendidikan, pemerintah, masyarakat sipil, anggota legislatif, media massa, dunia usaha dan dunia industri sehingga satuan pendidikan adalah komponen yang penting dalam pembangunan karakter yang berjalan secara sistemik dan integratif bersama dengan komponen lainnya. Dalam rangka mewujudkan fungsi tersebut, perlu diimplementasikan nilai karakter semangat kebangsaan dan cinta tanah air (Kemdikbud, 2011).

Nilai nilai pendidikan karakter di Indonesia teridentifikasi berjumlah 18 nilai, yang bersumber dari agama, Pancasila, budaya dan tujuan pendidikan nasional yaitu: 1 . Religius, 2. Jujur, 3.Toleransi, 4. Disiplin, 5.Kerja keras, 6. Kreatif, 7. Mandiri, 8. Demokratis, 9. Rasa Ingin Tahu, 10. Semangat kebangsaan, 11. Cinta tanah air, 12. Menghargai prestasi, 13. Bersahabat/komunikatif, 14. Cinta damai, 15.Gemar membaca, 16. Peduli lingkungan, 17. Peduli sosial dan 18. Tanggung jawab (Kemdikbud, 2011).

Semakin berkembangnya radikalisme beragama di tengah masyarakat menjadi ancaman bagi kesatuan bangsa Indonesia. Salah satu upaya strategis menangkal radikalisme beragama di Indonesia adalah melalui program pendidikan karakter semangat kebangsaan dan cinta tanah air di sekolah berlatar belakang islam.

\section{METODE PENELITIAN}

Pendekatan penelitian yang digunakan adalah pendekatan kualitatif termasuk dalam jenis penelitian studi kasus. Subyek penelitian ini adalah kepala sekolah, para guru dan para siswa di beberapa sekolah berlatar belakang islam di Kota Pasuruan, antara lain: SD Islam Terpadu Bina Insan Cendekia, SMP Islam Terpadu Fasihul Qur'an dan SMK Bayt Al Hikmah Kota Pasuruan. Alat pengumpul data adalah wawancara, observasi dan studi dokumen. Analisis data dilakukan dengan langkah-langkah reduksi data, kategorisasi, cek keabsahan data, penafsiran dan penyimpulan. Untuk pengecekan keabsahan data dengan menggunakan trianggulasi sumber dan trianggulasi teknik.

Subjek dalam penelitian ini adalah kepala sekolah, para guru dan siswa di tiga sekolah berlatar belakang islam di Kota Pasuruan. Dalam penelitian ini subjek dipilih secara selektif agar dapat menggambarkan pokok bahasan yang diteliti. Berdasarkan karakteristik yang ada, maka diperoleh dua belas orang subyek penelitian, yang meliputi dua orang kepala sekolah, lima orang guru dan lima orang siswa.

Teknik - teknik pengumpulan data yang digunakan dalam penelitian ini adalah wawancara, observasi dan studi dokumen. Dalam penelitian ini jenis wawancara yang dilakukan adalah wawancara mendalam. Wawancara mendalam berusaha mengumpulkan informasi berupa opini, perasaan, nilai dan sikap dari subyek penelitian. Wawancara ini dilaksanakan dengan menggunakan pedoman wawancara (protokol wawancara), yaitu petunjuk secara garis besar tentang proses dan isi wawancara untuk menjaga agar pokok pokok yang direncanakan dapat tercakup seluruhnya. Adapun jenis wawancara yang dilakukan pada subjek adalah wawancara semi terstruktur. Tujuan dari wawancara jenis ini adalah untuk menemukan permasalahan secara lebih terbuka, dimana pihak yang diajak wawancara dimintai pendapat dan ide - ide nya (Sugiyono, 2009).

Dalam observasi dalam penelitian ini, peneliti terlibat dengan kegiatan sehari - hari orang yang sedang diamati atau yang digunakan sebagai sumber data penelitian. Dengan observasi partisipatif ini, maka data yang diperoleh akan lebih lengkap, tajam dan sampai mengetahui pada tingkat makna dari setiap perilaku yang nampak (Neuman, 1999). Adapun jenis partisipasi yang dilakukan adalah partisipasi aktif, dimana peneliti datang di tempat kegiatan subyek yang diamati, tetapi tidak ikut terlibat dalam kegiatan tersebut.

Dokumen yang digunakan dalam penelitian ini adalah dokumen resmi dan 
dokumen pribadi. Dokumen resmi berupa arsip atau surat yang dikeluarkan oleh lembaga, sedangkan dokumen pribadi yaitu catatan atau keterangan seseorang tentang tindakan, pengalaman dan kepercayaannya (Zainudin, 2000).

Beberapa tahapan-tahapan penelitian kualitatif yang diterapkan dalam penelitian ini antara lain tahap pra lapangan, tahap pekerjaan lapangan dan tahap analisis data. Dalam tahap pra lapangan, ada enam tahap kegiatan yang harus dilakukan oleh peneliti dalam tahapan ini ditambah dengan satu pertimbangan yang perlu dipahami, yaitu etika penelitian lapangan. Enam tahapan tersebut adalah 1) Menyusun rancangan penelitian, 2) Memilih lapangan penelitian, 3) Mengurus perizinan, 4) Menjajaki dan menilai lapangan, 5) Memilih dan memanfaatkan informan, 6) Menyiapkan perlengkapan penelitian.

Pada tahap pekerjaan lapangan, dibagi atas tiga bagian yaitu: 1) Memahami latar penelitian, dan persiapan diri. Dalam hal ini, pokok-pokok yang harus diperhatikan adalah; a. Pembatasan latar dan peneliti, b. Penampilan, c. Pengenalan hubungan peneliti di lapangan, dan d. Jumlah waktu studi. 2) Memasuki lapangan, ketika memasuki lapangan maka hal yang perlu diperhatikan adalah; a. Keakraban hubungan, b. Mempelajari bahasa, c. Peranan peneliti sebagai pengumpul informasi. Yang terakhir adalah 3) Berperan serta sambil mengumpulkan data, dalam bagian ini hal yang harus diperhatikan adalah; a. Pengarahan batas studi, b. Mencatat data, c. Petunjuk tentang cara mengingat data, d. Kejenuhan, ketelitian dan istirahat, e. Meneliti suatu latar yang didalamnya terdapat pertentangan dan f. Analisis lapangan (Nasir, 1999).

Tahap analisis data dalam penelitian ini adalah dengan proses induksi, reduksi dan kategorisasi. Tahap induksi, dalam hal ini maksudnya adalah ketika peneliti mengumpulkan dan menyajikan tumpukan data pada tahap awal. Peneliti menyajikan data berupa kutipan langsung dari pandangan subyek dalam bahasa atau kalimat subyek yang bersangkutan. Tahap reduksi data, maksudnya adalah membuang data-data dari hasil wawancara dan observasi yang tidak mempunyai makna apapun, memilih yang penting sehubungan dengan penelitian dan mengumpulkan yang punya makna. Tahap kategorisasi, maksudnya adalah menyusun kategori dengan cara memilah-milah setiap satuan data ke dalam kelompok - kelompok data yang memiliki kesamaan. Langkah selanjutnya adalah membaca kembali hasil analisis data secara umum untuk mendapatkan sebuah kesimpulan (Sugiyono, 2009).

Adapun teknik pemeriksaan keabsahan data yang digunakan pada penelitian ini adalah trianggulasi sumber dan trianggulasi teknik. Trianggulasi sumber adalah pengecekan keabsahan data dengan cara mengecek data yang telah diperoleh melalui beberapa sumber. Sumber yang digunakan sebagai trianggulasi sumber dalam penelitian ini adalah a) karyawan sekolah, b) guru ekstrakulikuler dan c) orang tua siswa. Trianggulasi teknik adalah pengecekan keabsahan data dengan cara mengecek data kepada sumber yang sama dengan teknik yang berbeda. Dalam penelitian ini teknik yang digunakan sebagai trianggulasi adalah teknik wawancara, observasi dan studi dokumen yang dilakukan pada subyek.

\section{HASIL DAN PEMBAHASAN}

Hasil

Sekolah berlatar belakang islam di Kota Pasuruan yang dimaksud dalam penelitian ini adalah sekolah yang mengedepankan penanaman nilai-nilai islam pada anak didiknya, contohnya: baca, tulis dan pemahaman AlQuran, penerapan amalan ibadah wajib dan sunnah serta penerapan adab islami dalam kehidupan sehari-hari. Seperti pada umumnya sekolah islam, SD Islam Terpadu Bina Insan Cendekia, SMP Islam Terpadu Fasihul Quran dan SMK Bayt Al Hikmah Kota Pasuruan juga memiliki kebijakan tersendiri mengenai proses pembelajaran yang diberikan kepada anak-anak didiknya, baik pelajaran formal maupun yang bersifat nonformal, terkait dalam penanaman nilai-nilai keislaman di dalamnya. Namun demikian sebagai sekolah yang berada di bawah naungan Dinas Pendidikan, mereka harus mengikuti dan melaksanakan aturan-aturan Dinas Pendidikan setempat dalam hal pendidikan siswa-siswinya baik secara formal maupun non formal. 
Ketiga sekolah berlatar belakang islam di Kota Pasuruan ini memberikan karakter islami yang lebih kental dibandingkan dengan sekolahsekolah reguler lainnya, namun mereka tidak melupakan penanaman karakter-karakter lain yang mengacu pada kecintaannya kepada Negara Indonesia sehingga akan menumbuhkan semangat berkebangsaan.

Penanaman karakter kebangsaan pada para siswa salah satunya diberikan melalui mata pelajaran umum dan muatan lokal (mulok) di sekolah. Buku-buku mata pelajaran umum dan mulok di sana menggunakan buku yang sama dengan sekolah-sekolah negeri di Kota Pasuruan, hanya saja penyampaian materi palajaran tersebut dikaitkan dengan nilai-nilai keislaman. Misalnya saja pada pelajaran Pendidikan Kewarganegaraan (PKn), siswasiswi SDIT Bina Insan Cendekia diperkenalkan lambang Negara Indonesia serta wajib menghafalkan isi dari Pancasila. Selain itu juga pada pelajaran tersebut ditanamkan nilai-nilai semangat kebangsaan yang diambil dari keteladanan para pahlawan melalui kisah-kisah perjuangannya. Dari sisi keislaman yang bisa dimunculkan adalah kisah para pahlawan muslim yang ikut berperang melawan penjajah demi kemerdekaan Indonesia. Siswa-siswi di SMPIT Fasihul Quran juga diwajibkan menghafal lagu-lagu nasional sebagai bagian dari program pembelajaran karakter. Lagu-lagu nasional juga diberikan pada mata pelajaran SBK (Seni Budaya dan Kesenian). Dengan mengenal kisah-kisah dan lagu-lagu nasional, diharapkan dapat menumbuhkan rasa kecintaan siswa-siswi di sekolah-sekolah tersebut terhadap tanah air Indonesia.

Selain karakter kecintaan terhadap tanah air Indonesia, sekolah berlatar belakang islam di Kota Pasuruan juga menanamkan karakter semangat kebangsaan kepada siswa-siswinya, salah satunya adalah kegiatan rutin upacara bendera yang dilaksanakan setiap hari Senin. Di ketiga sekolah tersebut, setiap peserta didik diwajibkan mengikuti upacara bendera setiap hari Senin kecuali terdapat izin berhalangan yang dapat dibenarkan (udzur syar'i) seperti sakit atau tidak masuk sekolah karena suatu kepentingan keluarga, dan udzur syar'i lainnya.
Petugas pengibar bendera dilaksanakan oleh para siswa secara bergantian.

Selain upacara bendera setiap hari Senin, di sekolah berlatar belakang islam di Kota Pasuruan juga melaksanakan upacara pada hari besar nasional seperti Hari Pendidikan dan Hari Kemerdekaan Indonesia tanggal 17 Agustus. Selain upacara bendera, para siswa di SDIT Bina Insan Cendekia dan SMK Bayt Al Hikmah juga mengikuti serangkaian kegiatan peringatan Hari Kemerdekaan Indonesia seperti sepeda hias, karnaval mobil hias, lomba baris, gerak jalan dan kegiatan lainnya.

Ketiga sekolah berlatar belakang islam di Kota Pasuruan juga telah memfasilitasi implementasi pendidikan karakter semangat kebangsaan melalui kegiatan ekstrakulikuler yang terkait, seperti Pramuka, OSIS dan pemilihan Duta Karakter. Kegiatan ekstrakulikuler Pramuka berjalan dengan baik di ketiga sekolah tersebut. Setiap hari Sabtu para siswa diwajibkan untuk mengikuti kegiatan Pramuka di sekolah, meliputi pemahaman materi kepramukaan, baris-berbaris, tata apel dan upacara serta dinamika kelompok. Dalam kegiatan Pramuka ini, para siswa diajarkan tentang cinta tanah air dan nasionalisme, yang ini merupakan salah satu poin penting dalam Dasa Dharma Pramuka. Di SDIT Bina Insan Cendekia dan SMPIT Fasihul Quran terdapat program Pemilihan Duta Karakter Sekolah. Dalam program ini, sekolah menetapkan kriteria perilaku yang merupakan bentuk implementasi karakter positif yang wajib dijalankan oleh semua siswa. Semangat kebangsaan atau nasionalisme juga merupakan salah satu karakter yang diimplementasikan. Pelaksanaan perilaku-perilaku tersebut dievaluasi secara berkelanjutan kemudian di akhir semester akan dipilih beberapa siswa yang terbaik dalam mengimplemntasikan karakternya dan dinobatkan sebagai Duta Karakter Sekolah.

Namun kendati demikian, penyediaan sarana prasarana yang menunjang masih sangat minim, evaluasi dan tindak lanjut keberhasilan pendidikan karakter juga masih belum dilaksanakan. Hal ini menyebabkan nilai-nilai semangat kebangsaan dan cinta tanah air masih belum membudaya di sekolah-sekolah tersebut. 


\section{Pembahasan}

Mengacu pada definisi pendidikan karakter sebagaimana yang telah dirumuskan oleh Kementrian Pendidikan dan Kebudayaan Republik Indonesia, pendidikan karakter tidak hanya mengajarkan mana yang benar dan mana yang salah, akan tetapi lebih dari itu sehingga sekolah dalam mewujudkan pendidikan karakter harus menanamkan kebiasaan (habituation) tentang hal-hal mana yang benar dan baik sehingga peserta didik menjadi paham (kognitif) tentang mana yang benar dan mana yang tidak benar, peserta didik juga mampu merasakan (afektif) dan biasa melakukan (psikomotor) nilai-nilai yang baik. Pendidikan nilai di sekolah harus dilaksanakan melalui kajian dan pengembangan kurikulum yang sedang berlaku dan dilaksanakan secara berkesinambungan, yaitu mulai dari TK, SD, SMP, SMA, SMK bahkan sampai perguruan tinggi.

Nilai semangat kebangsaan adalah cara berpikir,bertindak dan wawasan yang menempatkan kepentingan bangsa dan negara di atas kepentingan diri dan kelompoknya. Nilai cinta tanah air adalah cara berpikir,bersikap dan berbuat yang menunjukkan kesetiaan, kepedulian dan penghargaan yang tinggi terhadap bahasa, lingkungan fisik, sosial, budaya, ekonomi dan politik bangsanya (Kemdikbud, 2011).

Made (2011) menjelaskan bahwa dalam mengimplikasikan pendidikan karakter dapat dilakukan dengan menggunakan tiga pendekatan, antara lain:

- Melalui kebijakan nasional yang diteruskan sampai ke tingkat satuan pendidikan (top down). Pendekatan ini dilakukan dengan tahapan sosialisasi, pengembangan regulasi, pengambangan kapasitas, implementasi dan kerjasama, monitoring dan evaluasi.

- Menemukenali praktek/contoh terbaik pendidikan karakter (bottom up). Pendekatan ini dilakukan dengan:

a. Penemuan dan berbagi pengalaman praktek terbaik pendidikan karakter tingkat satuan pendidikan di kab./kota, di provinsi sampai tingkat nasional.

b. Pendokumentasian praktek terbaik tersebut dalam buku, CD, dsb.

c. Revitalisasi kegiatan ekstrakurikuler.
Pendekatan ini dapat dilakukan melalui Pramuka, kantin kejujuran, UKS, PMR, perlombaan/olimpiade sains \& olah raga, sekolah hijau, pendidikan anti korupsi, pendidikan tertib lalu lintas.

Implementasi pendidikan karakter dalam Kurikulum Tingkat Satuan Pendidikan (KTSP) dilakukan dalam bentuk sebagai berikut:

- Integrasi dalam mata pelajaran yang ada.

Mengembangkan silabus dan Rencana Program Pembelajaran (RPP) pada kompetensi yang telah ada sesuai dengan nilai yang akan diterapkan.

- Mata Pelajaran dalam Muatan Lokal. Ditetapkan oleh sekolah / daerah. Kompetensi dikembangkan oleh sekolah / daerah

- Kegiatan Pengembangan Diri

Kegiatan pengembangan diri diwujudkan dalam:

a. Pembudayaan \& Pembiasaan.

Berupa pengkondisian, kegiatan rutin, kegiatan spontanitas, keteladanan, kegiatan terprogram.

b. Ektrakurikuler.

Kegiatan ekstrakulikuler seperti Pramuka; PMR; Kantin kejujuran; UKS; KIR; Olahraga, Seni; OSIS.

c. Bimbingan Konseling.

Bimbingan konseling berupa pemberian layanan bagi anak yang mengalani masalah.

Adapun tahapan-tahapan dalam pembentukan karakter adalah:

- Tahap Penanaman.

Tahapan penanaman dengan jalan dikenalkan contoh-contoh konkret yang baik dan buruk. Perlu dijelaskan konsekuensi positif dan negatifnya. Dalam proses ini perlu dipantau orang tua, guru dan masyarakat, yang salah dibetulkan dengan cara baik.

- Tahap Penumbuhan.

Hasil dari tahap "penanaman" selalu diingatkan, dibimbing dan dipantau. Jangan dicela atau dihina agar tumbuh dengan baik dalam hati sanubari.

- Tahapan Pengembangan. 
Tahapan pengembangan melalui kegiatan konkrit. Berikan kepercayaan melalui diskusi, permainan peran, simulasi dan lainlain. Dengan memainkan suatu peran anak akan lebih mudah menginternalisasi karakter sesuai potensinya.

- Tahap Pemantapan.

Dalam tahap pemantapan, anak diberi kesempatan untuk mengaktualisasikan diri dalam bentuk kegiatan nyata bersama teman dan masyarakat. Anak didorong untuk partisipasi aktif, bertanggung jawab dalam sikap, tindakan dan tutur kata.

Prosedur pelaksanaan pendidikan karakter pada satuan pendidikan adalah:

- Komitmen seluruh warga sekolah dan masyarakat sekitar untuk melaksanakan pendidikan karakter di sekolah.

- Melaksanakan analisis konteks untuk menetapkan sumberdaya dan sarana yang diperlakukan nilai-nilai dan indikator yang dikembangkan prosedur penilaian keberhasilan.

- Menyusun Rencana Kerja Sekolah (RKS) dan Rencana Aksi Sekolah (RAS) yang mengandung nilai-nilai karakter.

- Pemenuhan tagihan minimum pelaksanaan pendidikan karakter, yang mencakup penyiapan sumberdaya manusia, penyiapan dokumen kurikulum, penyediaan sarana dan prtasarana, alokasi waktu dan penjadwalan, pengkondisian, pembagian tugas dan tanggung jawab.

- Pelaksanaan pendidikan karakter di sekolah yang melibatkan seluruh warga sekolah atas dukungan masyarakat. Hal ini dapat diimplementasikan dengan keteladanan pendidik dan tenaga kependidikan dan program pembudayaan karakter di sekolah

- Penilaian keberhasilan, reward dan punishment serta tindak lanjut.

- Evaluasi diri terhadap program sekolah (Made, 2011).

Implementasi penididikan karakter di ketiga sekolah tersebut berupa penyusunan Rencana Kerja Sekolah (RKS) dan Rencana Aksi Sekolah (RAS) yang mengandung nilainilai semangat kebangsaan dan cinta tanah air, penyiapan sumber daya manusia, penyiapan dokumen kurikulum, pengalokasi waktu dan penjadwalan kegiatan ekstrakurikuler. Penanaman karakter semangat kebangsaan pada para siswa salah satunya diberikan melalui mata pelajaran umum dan muatan lokal (mulok) di sekolah. Peraturan sekolah mewajibkan para siswa menghafal lagu-lagu nasional sebagai bagian dari program pembelajaran karakter. Kegiatan rutin upacara bendera yang dilaksanakan setiap hari Senin dan Hari Besar Nasional tertentu. Mengikuti serangkaian kegiatan peringatan Hari Kemerdekaan Indonesia. Implementasi pendidikan karakter semangat kebangsaan melalui kegiatan ekstrakulikuler yang terkait, seperti Pramuka, OSIS dan pemilihan Duta Karakter.

\section{KESIMPULAN DAN SARAN \\ Kesimpulan}

Hasil penelitian menunjukkan bahwa telah terdapat komitmen pada ketiga pimpinan sekolah yang berlatar belakang Islam di Kota Pasuruan untuk melaksanakan pendidikan karakter semangat kebangsaan dan cinta tanah air. Telah dilakukan analisis konteks untuk menetapkan nilai-nilai dan indikator capaian dalam prosedur implementasi pendidikan karakter tersebut. Kendati demikian, penyediaan sarana prasarana yang menunjang masih sangat minim, evaluasi dan tindak lanjut keberhasilan pendidikan karakter juga masih belum dilaksanakan. Hal ini menyebabkan nilai-nilai semangat kebangsaan dan cinta tanah air masih belum membudaya di sekolah-sekolah tersebut.

\section{Saran}

Berdasarkan hasil penelitian disarankan bagi kepala sekolah bekerjasama dengan para guru, karyawan dan warga masyarakat dapat saling bekerjasama untuk lebih mengimplementasikan nilai-nilai karakter semangat kebangsaan dan cinta tanah air di sekolah. Semua bentuk kegiatan dalam rangka pendidikan karakter hendaknya dapat dievaluasi dan ditindak lanjuti, sehingga karakter semangat kebangsaan dan cinta tanah air dapat terbentuk dengan baik pada para pelajar dan warga sekolah lainnya. 
$1 \$$ Jurnal Sains Psikologi, Jilid 6, Nomor 1, Maret 2017, hlm 9-15

\section{DAFTAR RUJUKAN}

Danim. 2006. Visi Baru Manajemen Sekolah. Jakarta: Gramedia

Indrakusuma, Amir Daien. 1973. Pengantar ilmu pendidikan. Surabaya: Usaha Nasional.

Kemdikbud. 2011. Pedoman pelaksanaan pendidikan karakter. Jakarta: Kementrian Pendidikan Nasional Badan Penelitian dan

Pengembangan Pusat Kurikulum dan Perbukuan.

Made. 2011. Pengertian pendidikan karakter dan implementasinya di sekolah. Makalah disajikan dalam Seminar Pendidikan Karakter Fakultas Psikologi Universitas Airlangga, Surabaya, 20 November

Nazir, M. 1999. Metode penelitian. Jakarta: Ghalia Indonesia

Neuman, W.L. 1999. Social research methods: quantitative and qualitative approach. Massachusetts: Allyn and Bacon

Ormrod, J. 2008. Psikologi pendidikan edisi keenam. Jakarta: Penerbit Erlangga.

Sugiyono. 2009. Memahami penelitian Kualitatif. Bandung: Penerbit CV. Alfabeta

Tim Dosen KTP FIP IKIP Malang. (1995). Pengantar pendidikan. Malang: FIP IKIP Malang

Zainudin, M. 2000. Metodologi penelitian. Surabaya. 